\title{
Pengaruh Pembiayaan Jual Beli, Bagi Hasil, dan Pembiayaan Bermasalah Terhadap Kinerja Keuangan
}

\author{
Cicik Mutiah ${ }^{1 *}$, Wahab Wahab², Nurudin Nurudin ${ }^{3}$ \\ ${ }^{1}$ Jurusan Perbankan, Fakultas Ekonomi dan Bisnis Islam, UIN Walisongo Semarang, cicik.mutiah@gmail.com \\ 2 Jurusan Perbankan, Fakultas Ekonomi dan Bisnis Islam, UIN Walisongo Semarang, wahab@walisongo.ac.id \\ 3 Jurusan Perbankan, Fakultas Ekonomi dan Bisnis Islam, UIN Walisongo Semarang, nurudin@walisongo.ac.id
}

ABSTRAK

Penelitian ini bertujuan untuk mengetahui pengaruh pembiayaan jual beli, bagi hasil dan pembiayaan bermasalah terhadap kinerja keuangan pada bank BRI Syariah periode 2009-2019. Rumusan masalah dalam penelitian ini yaitu: 1) Untuk mengetahui apakah terdapat pengaruh pembiayaan jual beli terhadap kinerja keuangan pada bank BRI Syariah. 2) Untuk mengetahui apakah terdapat pengaruh pembiayaan bagi hasil terhadap kinerja keuangan pada bank BRI Syariah. Dan 3) Untuk mengetahui apakah terdapat pengaruh pembiayaan bermasalah terhadap kinerja keuangan pada bank BRI Syariah. Penelitian ini menggunakan metode kuantitatif dengan penelitian deskriptif. Data yang digunakan dalam penelitian ini adalah data sekunder yang diperoleh dari website resmi bank BRI Syariah dan Otoritas Jasa Keuangan (OJK), Laporan Keuangan Triwulan tahun 2009 hingga tahun 2019. Model analisis yang digunakan dalam penelitian ini yaitu model Regresi Berganda menggunakan SPSS 16.0. Sedangkan teknik analisis yang digunakan adalah uji parsial (uji t) dan uji signifikansi koefisien determinasi $\left(\mathrm{R}^{2}\right)$. Penelitian ini memberikan hasil bahwa pembiayaan jual beli berpengaruh positif tetapi tidak signifikan terhadap kinerja keuangan yang diproksi ROA, pembiayaann bagi hasil berpengaruh negatif dan tidak signifikan terhadap kinerja keuangan yang diproksi ROA, dan pembiayaan bermasalah berpengaruh dan signifikan terhadap kinerja keuangan yang diproksi ROA. Nilai $\mathrm{R}^{2}$ dalam penelitian ini sebesar 30,3\% sehingga variabel kinerja keuangan dapat dijelaskan oleh variabel pembiayaan jual beli, bagi hasil dan pembiayaan bermasalah. Sedangkan sisanya 69,7\% dijelaskan dalam variabel lain di luar penelitian.
INFORMASI ARTIKEL

Katakunci:

Pembiayaan Jual Beli, Pembiayaan Bagi Hasil, Pembiayaan Bermasalah dan Kinerja Keuangan. 


\section{PENDAHULUAN}

Undang-undang Perbankan Syariah Indonesia No. 21 Tahun 2008 tentang Perbankan Syariah merupakan salah satu dari faktor dimana menyebabkan perbankan syariah di Indonesia semakin pesat. ${ }^{1}$ Kegiatan usaha Perbankan Syariah berjalan sesuai dengan prinsip syariah yang terdiri dari Bank Umum Syariah (BUS) dan Bank Pembiayaan Rakyat Syariah (BPRS). BUS adalah bank syariah dalam kegiatan usahanya memberikan jasa dan lalu lintas pembayaran. Dalam UU tersebut juga dikatakan bahwa bank konvensional yang hendak melaksanakan usaha syariah harus membentuk Unit Usaha Syariah (UUS) yang khusus beroperasi dengan sistem syariah. $^{2}$

Pembiayaan yang disalurkan oleh bank syariah memungkinkan didalamnya mengandung resiko. Salah satunya pembiayaan yang mengandung resiko yaitu pembiayaan bermasalah (non performing finance). Pembiayaan bermasalah yaitu suatu pinjaman dimana kesulitan dalam pelunasan yang diakibatkan oleh faktor kesenjangan atau faktor diluar kemampuan/kendali nasabah yang peminjam. Kualitas pembiayaan digolongkan menjadi lima yaitu lancar, dalam perhatian khusus, kurang lancar, diragukan, dan macet. Kategori pembiayaan bermasalah yaitu dimana kualitas pembiayaan masuk dari

\footnotetext{
${ }^{1}$ Achmad Syaiful Nizar, Moch. Khoirul Anwar, "Pengaruh Pembiayaan Jual Beli, Pembiayaan Bagi Hasil dan Intellectual Capital Terhadap Kinerja Keuangan Syariah”, Jurnal Akrual 6 (2) (2015): 127-143 e-ISSN: 2502-6380, h. 128.

${ }^{2}$ Atieq Amjadallah Alfie, maftuchatul Khanifah, Pembiayaan Natural Certainty Contract (NCC) dan Pembiayaan Natural Uncertainty Contract (NUC) Pada Profitabilitas Bank Umum Syariah, disusun oleh mahasiswa Fakultas Ekonomi Universitas Wahid Hasyim, 2017 h. 15.
}

golongan dalam perhatian khusus sampai golongan macet. Besar maupun kecilnya suatu pembiayaan bermasalah (non performing financing) menunjukkan kinerja bank dalam pengelolaan dana. Apabila pembiayaan bermasalah membesar, berarati pendapatan yang diperoleh bank pada akhirnya akan menurun. ${ }^{3}$

\section{Komposisi pembiayaan Bank BRI Syariah tahun 2009-2019}

\begin{tabular}{|c|c|c|}
\hline Tahun & $\begin{array}{c}\text { Pembiayaan Jual } \\
\text { Beli } \\
\text { (dalam Jutaan } \\
\text { Rupiah) }\end{array}$ & $\begin{array}{c}\text { Pembiayaan } \\
\text { Bagi Hasil } \\
\text { (dalam } \\
\text { Jutaan } \\
\text { Rupiah) }\end{array}$ \\
\hline 2009 & 1.780 .457 & 771.230 \\
\hline 2010 & 3.498 .291 & 1.328 .992 \\
\hline 2011 & 5.410 .089 & 1.760 .141 \\
\hline 2012 & 7.161 .116 & 2.663 .262 \\
\hline 2013 & 9.028 .278 & 4.050 .478 \\
\hline 2014 & 10.039 .361 & 4.976 .583 \\
\hline 2015 & 10.010 .703 & 6.204 .430 \\
\hline 2016 & 10.788 .143 & 6.665 .412 \\
\hline 2017 & 10.891 .386 & 6.435 .239 \\
\hline 2018 & 11.578 .420 & 8.232 .976 \\
\hline 2019 & 13.562 .426 & 11.797 .117 \\
\hline \multicolumn{2}{|c|}{ Sumber: Laporan Tahunan Annual Report } \\
\multicolumn{3}{|c}{ BRISyariah dan OJK diolah }
\end{tabular}

Dari Tabel diatas dapat dilihat bahwa Variabel Pembiayaan Jual beli pada tahun 2009 sampai 2019 mengalami kenaikan dan penurunan. Dimana pembiayaan jual beli pada tahun 2009 sebesar 1.780.457 Juta Rupiah. Pada tahun 2010 sampai 2015 selalu meningkat. Di tahun 2010 jumlah pembiayaan sebesar 3.498.291 Juta Rupiah, Tahun 2011 sebesar 5.410.089 Juta Rupiah. Dan tahun 2012 sebesar 7.161.116 Juta Rupiah. Pada tahun 2013 sebesar 9.028.278 Juta Rupiah, tahun 
2014 sebesar 10.039.361 Juta Rupiah, dan tahun 2015 menurun sebesar 10.010.703 Juta Rupiah. pada tahun 2016 sampai tahun 2019 selalu meningkat dimana pada tahun 2016 sebesar 10.788.143 juta Rupiah. Pada tahun 2017 pembiayaan jual beli sebesar 10.891.386 Juta Rupiah. Tahun 2018 sebesar 11.578.420 Juta Rupiah dan pada tahun 2019 sebesar 13.562.426 Juta Rupiah.

Variabel pembiayaan bagi hasil setiap tahunnya mengalami penurunan dan kenaikan. dimana pembiayaan bagi hasil pada tahun 2009 sebesar 771.230 Juta Rupiah. Pada tahun 2010 sampai 2016 selalu meningkat. Di tahun 2010 jumlah pembiayaan sebesar 1.328.992 Juta Rupiah, Tahun 2011 sebesar 1.760.141 Juta Rupiah. Dan tahun 2012 sebesar 2.663.262 Juta Rupiah. Pada tahun 2013 sebesar 4.050.478 Juta Rupiah, tahun 2014 sebesar 4.976.583 Juta Rupiah, dan tahun 2015 sebesar 6.204.430 Juta Rupiah. Pada tahun 2016 sebesar 6.665.412 juta Rupiah. Tetapi pada tahun 2017 pembiayaan jual beli mengalami penurunan sebesar 6.435.239 Juta Rupiah. Pada tahun 2018 meningkat kembali dengan total pembiayaan sebesar 8.232.976 Juta Rupiah dan pada tahun 2019 terus meningkat sebesar 11.797.117 Juta Rupiah.

Dalam penelitian ini peneliti memilih variabel yang dipakai untuk meningkatkan kinerja keuangan dengan meningkatkannya pembiayaanpembiayaan yaitu adanya pembiayaan jual beli, pembiayaan bagi hasil dan dalam penyaluran pembiayaan yaitu pembiayaan bermasalah (Non Performing Financing). Pembiayaan jual beli merupakan suatu penyaluran dana berupa pembiayaan menggunakan prinsip jual beli dimana keuntungan disebut margin. Jenis-jenis pembiayaan jual beli yaitu murabahah, salam dan Istishna'.4

Non Performing Finance (NPF) Pembiayaan bermasalah adalah suatu penyaluran dana yang dilakukan oleh lembaga pembiayaan seperti bank syariah yang dalam pelaksaaan pembayaran pembiayaan oleh nasabah itu terjadi hal-hal seperti pembiayaan yang tidak lancar, pembiayaan debiturnya tidak memenuhi persyaratan yang dijanjikan, dan pembiayaan dimana jadwal angsurannya tidak ditepati. Sehingga berdampak negative bagi kedua belah pihak (debitur dan kreditur).

Hasil ROA dan NPF pada Bank BRI Syariah periode tahun 2009-2019

\begin{tabular}{|c|c|c|}
\hline Tahun & $\begin{array}{c}\text { ROA } \\
(\%)\end{array}$ & $\begin{array}{c}\text { NPF } \\
(\%)\end{array}$ \\
\hline 2009 & 0.52 & 3.20 \\
\hline 2010 & 0.35 & 3.19 \\
\hline 2011 & 0.20 & 2.77 \\
\hline 2012 & 1.19 & 3.00 \\
\hline 2013 & 1.15 & 3.06 \\
\hline 2014 & 0.08 & 4.60 \\
\hline 2015 & 0.77 & 4.86 \\
\hline 2016 & 0.95 & 4.57 \\
\hline 2017 & 0.51 & 6.43 \\
\hline 2018 & 0.43 & 6.73 \\
\hline 2019 & 0.31 & 5.22 \\
\hline
\end{tabular}

Sumber: Laporan Tahunan Annual Report Bank BRI Syariah dan OJK diolah

Dari tabel diatas dapat dilihat bahwa Return On Asset (ROA) dari tahun ke tahun mengalami pertumbuhan dan penurunan yang terjadi tiap tahunnya. Jika dilihat dari perhitungan ROA Tahun 2009 menuju ke tahun 2011 pada bank BRI Syariah mengalami penurunan. Tahun 2009 sebesar $0,52 \%$, 2010 sebesar $0,35 \%$, tahun

${ }^{4}$ Muhammad Syafi'i Antonio, Bank Syariah dari Teori ke Praktik, Jakarta: Gema Insani, 2001, h. 101. 
2011 sebesar 0,20\%. Tetapi pada tahun 2012 dan 2013 meningkat dengan angka $1.19 \%$ dan 1,15\%. Pada tahun 2014 kembali menurun dengan angka sebesar $0,08 \%$. Meningkat kembali pada tahun 2015 sebesar 0,77\% dan tahun 2016 sebesar 0,95\%. tetapi pada tahun 2016 sampai 2019 nilai ROA mengalami penurunan secara terus menerus. Dimana pada tahun 2017 sebesar 0,51\%, tahun 2018 sebesar $0,43 \%$ dan pada tahun 2019 sebesar 0,31\%.

Pada variabel pembiayaan bermasalah dari tahun 2009 sampai tahun 2019 mengalami penurunan dan kenaikan. Tahun 2009 sebesar 3,20\% dan tahun 2010 menurun sebesar 3,19\%. Pada tahun 2011 menurun kembali sebesar 2,77\%. Pada tahun 2012 mengalami peningkatan kembali sebesar 3,00\%. Di tahun 2013 sampai 2015 meningkat kembali sebesar $3.00 \%$, di tahun 2014 sebesar 4,60\%, tahun 2014 sebesar 4,86\%. Menurun pada tahun 2015 sebesar 4,57\%. Tetapi pada tahun 2017 dan tahun 2018 meningkat sebesar $6,43 \%$ dan 6,73\%. Selanjutnya pada tahun 2019 menurun sebesar 5,22\%.

Dari sisi rasio pembiayaan bermasalah (NPF) gross, hingga akhir Desember 2018 tercatat meningkat menjadi 6,73\% dari tahun sebelumnya $6,43 \%$. Adapun NPF nett tercatat sebesar $4,97 \%$ dari tahun sebelumnya $4,72 \%$. (CNBC Indonesia, 04 April 2019).

Berdasarkan fenomena gap diatas, kejadian yang ada pada data Bank BRI Syariah tahun 2009-2019 tidak selalu sama dengan teori yang ada. Hal ini juga didukung dengan adanya research gap dari penelitian sebelumnya. Terdapat hasil penelitian yang berbeda mengenai pengaruh pembiayaan-pembiayaan terhadap kinerja keuangan pada bank.Kondisi inilah yang melatarbelakangi penulis untuk melakukan penelitian karena adanya perbedaan antara teori yang seharusnya dengan data yang ada di lapangan, dan berdasarkan fenomena gap yang terjadi pada data Bank BRI Syariah periode 2009-2019 serta adanya research gap pada penelitian terdahulu maka perlu dilakukan penelitian lebih lanjut mengenai Pengaruh Pembiayaaan, Jual Beli, Bagi Hasil dan Pembiayaan Bermasalah Terhadap Kinerja Keuangan (Studi Kasus Pada Bank SRI Syariah Tahun 2009-2019).

\section{TINJAUAN PUSTAKA}

\subsection{Penelitian Terdahulu}

Menurut Penelitian Achmad Syaiful Nizar dan Moch. Khoirul Anwar (2014) variabel yang di diambil adalah pembiayaan jual beli, pembiayaan bagi hasil, dan intellectual capital. Penelitian Yuyun agustina (2014) Profitabilitas Bank Umum Syariah dipengaruhi oleh pembiayaan jual beli, pembiayaan bagi hasil dan NPF. Penelitian Slamet Riyadi dan Agung Yulianto (2014) profitabilitas dipengaruhi oleh pembiayaan bagi hasil, pembiayaan jual beli, Financing to Deposito Ratio (FDR) dan Non Performing Financing (NPF). Penelitian Ian Azhar dan Arim (2016) variabel yang diambil dalam penelitian yaitu pembiayaan jual beli, dan Non Performing Finance. Penelitian Novi Fadhila (2017) Profitabilitas Bank Syariah Mandiri dipengaruhi oleh pembiayaan bagi hasil dan pembiayaan murabahah.

Penelitian Cut Faradila, dkk (2017) Profitabilitas Bank Umum di Indonesia dipengaruhi oleh pembiayaan murabahah, Istishna, dan pembiayaan Ijarah. Penelitian Nur Kholis, Lintang 
Kurniawan (2018) Retun On Asset (ROA) Bank Umum Syariah dipengaruhi oleh pembiayaan bagi hasil dan Non Performing Financing (NPF). Medina Almunawwaroh dan Rina Marlina (2018) Profitabilitas Bank Umum Syariah di Indonesia dipengaruhi oleh CAR, NPF dan FDR. Penelitian Arif Syawaludin Mustofa (2019) kinerja keuangan pada Bank Umum Syariah dipengaruhi oleh pembiayaan mudharabah, musyarakah, murabahah dan ijarah. Penelitian Ana Fitriyani, dkk (2019) Profitabilitas Bank Umum Syariah dipengaruhi oleh pembiayaan Murabahah, Mudharabah dan Non Performing Financing (NPF).

Pada penelitian Ian Azhar, Arim (2016) menunjukkan hasil bahwa pembiayaan jual beli pengaruh terhadap profitabilitas yang diproksi ROA. Berbeda dengan penelitian Achmad Syaiful Nizar, Moch. Khoirul Anwar (2014), Slamet Riyadi (2014), dan Yuyun Agustina (2014) menunjukkan bahwa pembiayaan jual beli tidak berpengaruh ROA.

Pada penelitian Ian Azhar, Arim (2016), Slamet Riyadi (2014), menunjukkan bahwa pembiayaan bagi hasil berpengaruh terhadap ROA. Berbeda dengan penelitian Achmad Syaiful Nizar, Moch. Khoirul Anwar (2014), Yuyun Agustina (2014), Nur Kholis, Lintang Kurniawati (2018) menunjukkan bahwa pembiayaan bagi hasil tidak berpengaruh terhadap ROA.

Pada penelitian Ian Azhar, Arim (2016), Medina Almunawwaroh, Rina Marlina (2018), dan Nur Kholis, Lintang Kurniawati (2018) menunjukkan bahwa NPF berpengaruh terhadap ROA. Berbeda dengan penelitian Yuyun Agustina (2014), Ana Fitriyawati, dkk
(2019) menunjukkan bahwa NPF tidak berpengaruh terhadap ROA.

\subsection{Bank Syariah}

Bank berasal dari kata bangue (Bahasa Perancis) dan kata dari banco (Bahasa Italia) yang berasal peti/lemari atau bangku. Dimana menjelaskan fungsi dasar dari bank komersial, yaitu: menyediakan tempat untuk menitipkan uang dengan aman (safe keeping function), dan menyediakan alat pembayaran untuk membeli barang dan jasa (transaction function). ${ }^{5}$

Sedangkan menurut kamus Besar Bahasa Indonesia bank diartikan sebagai lembaga keuangan yang usaha pokoknya memberikan kredit dan jasa dalam lalu lintas pembayaran dan peredaran uang.

Bank Islam selanjutnya disebut dengan bank syariah adalah dimana bank beroperasi dengan tidak mengandalkan bunga. Bank islam atau sering disebut bank tanpa bunga adalah lembaga perbankan yang operasional dan produknya berkembang yang berlandaskan Al-Qur'an dan Hadits Nabi SAW. Dengan kata lain, Bank Islam adalah lembaga keuangan dimana usaha pokoknya memberikan pembiayaan serta jasa-jasa lainnya dalam lalu lintas pembayaran serta peredaran uang yang dioperasikan sesuai dengan prinsip syariah. ${ }^{6}$

Menurut Undang-undang No. 21 Tahun 2008, bank syariah merupakan badan usaha yang menjalankan usahanya sesuai dengan prinsip syariah

${ }^{5}$ M. Syafi'”i Antonio, Dasar-dasar Manajemen Bank Syariah, Jakarta: Pustaka Alfabeta, 2006, cet ke4, h. 2.

${ }^{6}$ Setia Budi Wilardjo, "Pengertian, Peranan dan Perkembangan Bank Syariah d Indonesia", Jurnal VALUE ADDED, Vol. 2, No. 1, September 2004-Maret 2005, h. 2. 
dan menurut jenisnya terdiri dari Bank Umum Syariah dan Bank Pembiayaan Rakyat Syariah. ${ }^{7}$

Dunia perbankan dewasa ini telah menyadari bahwa nasabah saat ini tidak hanya mempertimbangkan bank apa saja tempat mereka menabung atau berinvestasi, tidak hanya mempertimbangkan bunga atau keuntungan yang akan didapatkan dalam perbankan tersebut, akan tetapi nasabah juga membutuhkan kecanggihan dan kelengkapan fitur dari suatu produk perbankan, karena saat ini yang dicari oleh nasabah tidak hanya value(nilai) yang akan didapatkan dari apa yang ditawarkanoleh pihak bank tersebut, melainkan kualitas dan kemudahankemudahan yang dapat membantu dan memperlancar transaksi nasabah tersebut. 8

\section{Prinsip-prinsip Bank Syariah}

Prinsip bank syariah berlandasan pada Al-Qur'an dan As-Sunnah. Falsafah dasar peroperasian bank syariah mempunyai tiga prinsip yaitu efisien, keadilan, dan kebersamaan. Dimana efisien -terdapat pada prinsip saling membantu dimana agar mendapatkan margin lebih banyak. Pada prinsip Keadilan, dimana hubungan yang tidak ada kecurangan dan ikhlas sesuai proporsi. Kemudian kebersamaan dimana prinsip yang berkaitan untuk memberikan nasihat demi meningkatkan produktivitas.

${ }^{7}$ M. Nur Rianto Al-Arif, Lembaga Keuangan Syariah Suatu Kajian Teoritis Praktis, Jakarta: PT Pustaka Utama Grafiti, 2007, cet ke 3, h. 1.

${ }^{8}$ Nurdin, dkk (2020)", Pengaruh pelaanan mobile banking terhadap kepuasan nasabah, Jurnal Ilmu Perankan dan Keuangan Syariah, 2 (1) ,87-104

\section{Dasar Hukum Bank Syariah}

Dasar hukum utama dalam mengoperasionalkan bank syariah adalah Al-Qur'an dan Hadits. Berikut ini akan dinukilkan beberapa ayat-ayat dalam Al-Qur'an, antara lain:

(QS. Al-Baqarah: 275)

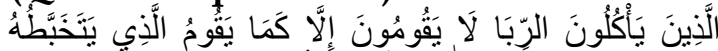

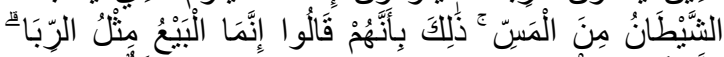

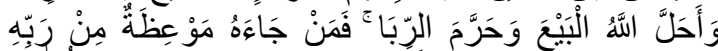

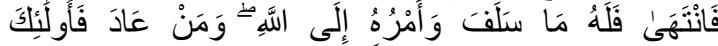

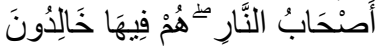

Terjemahan :

“Orang-orang yang Makan (mengambil) ribatidak dapat berdiri melainkan seperti berdirinya orang yang kemasukan syaitan lantaran (tekanan) penyakit gila. Keadaan mereka yang demikian itu, adalah disebabkan mereka berkata (berpendapat), Sesungguhnya jual beli itu sama dengan riba, Padahal Allah telah menghalalkan jual beli dan mengharamkan riba. orang-orang yang telah sampai kepadanya larangan dari Tuhannya, lalu terus berhenti (dari mengambil riba), Maka baginya apa yang telah diambilnya dahulu (sebelum datang larangan); dan urusannya (terserah) kepada Allah. orang yang kembali (mengambil riba), Maka orang itu adalah penghuni-penghuni neraka; mereka kekal di dalamnya".

\section{Al-Hadits :

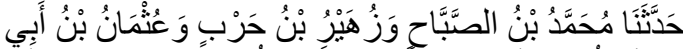

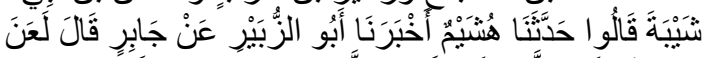

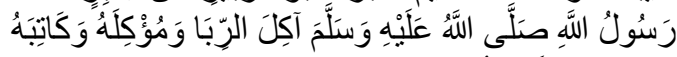

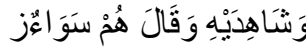 \\ Dari Jabir ra berkata, bahwa "Rasulullah SAW melaknat memakan Riba, orang yang menyuruh makan riba, juru tulisnya dan saksi-saksinya." Dan berkata, "Mereka semua sama".}


Peraturan Perundangan Tentang Perbankan Syariah

Bank adalah Bank Umum sebagaimana dimaksud dalam Undang-Undang Nomor 7 Tahun 1992 Tentang Perbankan sebagaimana telah diubah dengan Undang-Undang Nomor 10 Tahun 1998, termasuk kantor cabang dari bank yang berkedudukan di luar negeri, dan Bank Umum Syariah serta Unit Usaha Syariah sebagaimana dimaksud dalam Undang-Undang Nomor 21 Tahun 2008 tentang Perbankan Syariah. ${ }^{9}, 10$

\subsection{Pembiayaan Bank Syariah}

\section{Pengertian Pembiayaan}

Dalam UU Nomor 10 Tahun 1998 disebutkan bahwa pembiayaan yang berdasarkan syariah yaitu penyediaan uang atau tagihan dipersamakan dengan itu berdasarkan persetujuan atau kesepakatan antara bank dengan pihak lain yang mewajibkan pihak yang diberikan pembiayaan supaya dalam pelunasan sesuai waktu yang ditentukan dan imbalan disebut bagi hasil.

Istilah pembiayaan yang intinya yaitu memberikan kepercayaan. Dimana lembaga pembiayaan selaku sahib al-mal yang menaruh kepercayaan kepada seseorang untuk melaksanakan amanah yang diberi. Dananya harus digunakan dengan benar, adil, harus disertai

${ }^{9}$ Salinan Peraturan Otoritas Jasa Keuangan Nomor 2/POJK.03/2016 Tentang Pengembangan Jaringan Kantor Perbankan Syariah dalam Rangka Stimulus Perekonomian Nasional Bagi Bank.

${ }^{10}$ Malarangan, H., Irfan, I., Haekal, A., \& Istiqamah, R. (2020). Analisis Tanggung Jawab Pegadaian Syariah Palu Plaza Terhadap Barang Jaminan yang Hilang dan Rusak Jurnal Ilmu Ekonomi dan Bisnis Islam, 2(1), 15-35. dengan ikatan dan syarat-syarat yang jelas dan saling menguntungkan bagi kedua belah pihak. ${ }^{11}$

\section{Dasar Hukum Pembiayaan \\ Q.S Shaad : 4

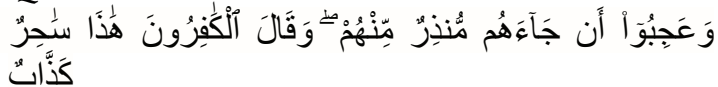

Daud berkata: "dan Sesungguhnya kebanyakan dari orang-orang yang berserikat itu sebahagian mereka berbuat zalim kepada sebahagian yang lain, kecuali orang-orang yang beriman dan mengerjakan amal yang saleh; dan Amat sedikitlah mereka ini".

\section{Al-Hadits :}

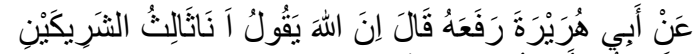

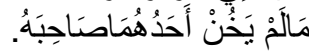

Dari Abu Hurairah, Rasulullah SAW bersabda, "Allah berfirman: Aku adalah pihak ketiga dari dua orang yang bersyariakat selama salah satunya tidak mengkhianati satu sama lain.(HR. Abu Dawud No. 2936, dalam kitab Al-Buyu dan Hakim).

\section{Tujuan pembiayaan}

a. Meningkatnya ekonomi masyarakat.

b. Tersedia dana untuk peningkatan usaha.

c. Meningkatkan produktivitas.

d. Menyediakan lowongan pekerjaan.

e. Terdapat distibusi pedapatan.

Adapun secara mikro, pembiayaan bertujuan untuk:

a. Upaya memperbanyak laba.

b. Meminimalisir resiko.

c. Pengembangkan sumber daya ekonomi.

d. Penyaluran kelebihan dana.

\section{Fungsi Pembiayaan}

${ }^{11}$ Viethzal Rivai dan Andria Permata Veithzal, Islamic Financial Management Jakarta: Raha Grafindo Persada, 2008, h. 3. 
a. Meningkatkan daya guna uang

b. Meningkatkan daya guna barang

c. Meningkatkan peredaran uang

d. Menimbulkan kegairahan berusaha

\section{Jenis-Jenis Pembiayaan}

a. Pembiayaan menurut tujuan

b. Pembiayaan menurut jangka waktu

\subsection{Pembiayaan Jual Beli}

Jual beli (buyu', jamak dari ba'i) atau perdagangan atau perniagaan menurut terminologi Fiqih Islam adalah alat tukar harta berdasarkan saling ridha (rela), atau berpindahnya kepemilikan dengan imbalan pada suatu yang diperbolehkan. Jual beli diperbolehkan Syariah berdasarkan Al-Qur-an, Sunnah, dan Ijmak (konsensus) para lama. Dalam al-Qur'an Surah Al-Baqarah : 275 sebagai berikut:

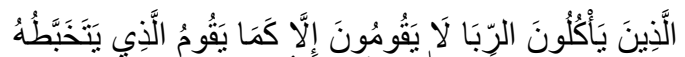

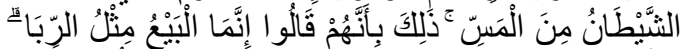

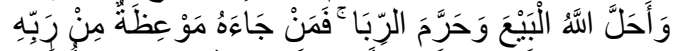

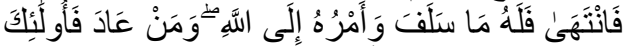

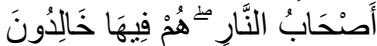

Terjemahan :

“Orang-orang yang Makan (mengambil) riba tidak dapat berdiri melainkan seperti berdirinya orang yang kemasukan syaitan lantaran (tekanan) penyakit gila. Keadaan mereka yang demikian itu, adalah disebabkan mereka berkata (berpendapat), Sesungguhnya jual beli itu sama dengan riba, Padahal Allah telah menghalalkan jual beli dan mengharamkan riba. orang-orang yang telah sampai kepadanya larangan dari Tuhannya, lalu terus berhenti (dari mengambil riba), Maka baginya apa yang telah diambilnya dahulu (sebelum datang larangan); dan urusannya (terserah) kepada Allah. orang yang kembali (mengambil riba), Maka orang itu adalah penghuni-penghuni neraka; mereka kekal di dalamnya".

Jenis-jenis akad jual beli yang dibahas para ulama dalam fiqih muamalah islamiah bisa dikatakan sangat banyak. Dari sekian banyaknya terdapat beberapa jenis akad jual beli dalam pembiayaan modal kerja dan investasi dalam perbankan syariah, yaitu akad murabahah, akad salam dan akad Istishna'.12,13

\section{Akad Murabahah}

Pembiayaan Murabahah (al-bai' tsaman ajil) sering dikenal dengan sebutan murabahah saja. Murabahah yang berasal dari kata "ribhu" (Keuntungan) adalah suatu transaksi jual beli dimana pihak bank menyebutkan jumlah keuntungannya. Bank sebagai penjual, dan sedangkan nasabah sebagai pembeli. Harga jual yaitu harga beli bank dari pemasok ditambah dengan keuntungan (margin). Kedua belah pihak harus menyepakati harga jual dan jangka waktu pembayaran. Harga jual dicantumkan pada akad jual beli dan jika telah disepakati tidak dapat berubah selama berlakunya akad. Dalam perbankan, murabahah selalu dilakukan dengan cara pembiayaan angsuran (bai bitsaman ajil atau muajjal). Dalam transaksi ini barang diserahkan secara langsung

12 Nurdin, N., \& Yusuf, K. (2020). Knowledge management lifecycle in Islamic bank: the case of syariah banks in Indonesia. International Journal of Knowledge Management Studies, 11(1), 59-80. doi: 10.1504/ijkms.2020.105073

${ }^{13}$ Nurdin, N., Pettalongi, S. S., \& Yusuf, K. (2018, 27-28 Sept. 2018). Knowledge Management Model in Syariah Banking. Paper presented at the 2018 5th International Conference on Information Technology, Computer, and Electrical Engineering (ICITACEE). 
setelah akad, sedangkan pembayaran dilakukan secara tangguh atau angsuran. ${ }^{14}$

\section{Akad Salam}

Transaksi Salam adalah pesan barang yang disebutkan sifat-sifatnya, yang dalam transaksi tersebut menjadi tanggungan penerima pesenan. ${ }^{15}$ Menurut Sayyid dalam Fiqih Sunnahnya, As-Salam dinamakan juga salaf (pendahuluan) yaitu jual beli barang dengan kriteria tertentu dengan pembayaran sekarang namun barang diterima dikemudian. 16. Dalam akad salam, secara umum dimana barang yang dipesan lebih dulu diketahui karakteristiknya meliputi jenis, spesifikasi teknik, kualitas, dan kuantitasnya.

\section{Akad Istishna'}

Menurut PSAK 104 Istishna' adalah akad jual beli dalam bentuk pemesanan pembuatan pembuatan barang tertentu dengan kriteria dan persyaratan tertentu yang disepakati antara pemesan (pembeli, mustashni') dan penjual (pembuat, shani'). ${ }^{17}$ Produk Istishna' menyerupai produk salam, tapi dalam istishna' pembayarannya dapat dilakukan oleh bank dalam beberapa transaksi (termin) pembayaran. ${ }^{18}$

2.5 Pembiayaan Bagi Hasil

\footnotetext{
${ }^{14}$ Rahmat Hidayat, Efisiensi Perbankan Syariah Teori dan Praktik, Bekasi: Gramata Publishing, 2014. h. 32.

${ }^{15}$ Atieq Amjadallah Alfie, Maftuchatul Khanifah, Pembiayaan..., h. 9.

${ }^{16}$ Ikit, Manajemen .., h. 127.

${ }^{17}$ Ikit, Manajemen ..., h. 133.

${ }^{18}$ Yuyun Agustina, "Pengaruh Pembiayaan Jual Beli, Pembiayaan Bagi Hasil dan Rasio Non Performing Financing (NPF) Terhadap Profitabilitas (ROA) Bank Umum Syariah di Indonesia”, Jurnal Yuyun Agustina-Ekonomi dan Bisnis, UMS 2013, h. 5.
}

Pembiayaan bagi hasil adalah akad kerja sama antara bank dengan nasabah, dimana bank sebagai pemilik modal sedangkan nasabah sebagai pengelola modal untuk memperoleh keuntungan dan keuntungan yang diperoleh berdasarkan kesepakatan atau nisbah yang telah disepakati. ${ }^{19}$

Pembiayaan bagi hasil dalam perbankan syariah mempunyai empat akad, yaitu akad musyarakah, mudharabah, muzara'ah, dan musaqah. Tetapi pembiayaan yang sering digunakan digunakan yaitu akad musyarakah dan akad mudharabah sedangkan almuzara'ah dan al-musaqah biasanya untuk pembiayaan pertanian pada bank Islam. ${ }^{20}$

\section{Akad Musyarakah}

Musyarakah berasal dari bahasa Arab syirkah yang artinya percampuran. Dalam hal berarti ini pencampuran antara satu modal dengan modal lainnya sehingga tidak bisa dipisahkan dan tidak boleh dibedakan oleh satu bagian dengan bagian lainnya. Sedangkan menurut makna Syara, Syirkah adalah kontrak antara dua atau lebih pihak-pihak yang setuju untuk melakukan pekerjaan dengan tujuan mendapatkan keuntungan. ${ }^{21}$

Kontrak musyarakah adalah transaksi investasi dua atau lebih pemilik dana dan/barang untuk mengamankan bisnis tertentu sesuai

\footnotetext{
${ }^{19}$ Achmad Syaiful Nizar, Moch. Khoirul Anwar, Pengaruh...,. h. 130.

${ }^{20}$ Muhammad Syafii Antonio, Bank Syariah ..., h. 90.

21 Nur Huda, Fitri Fajri, "The Analysis Of Musyarakah Contract Sharing System Implementationin BPRS Saka Dana Mulia Kudus”, AL-ARBAH:Journal of Islamic Financing and Banking. Vol. 1 No. 1 (2019), 95-106; DOI: 10.21580/al-arbah.2019.1.1.4159. h. 95.
} 
dengan syariah oleh distribusi hasil bisnis antara kedua pihak berdasarkan rasio yang disepakati, sedangkan pembagian kerugian proporsi modal masing-masing. ${ }^{22}$

Musyarakah Adalah pembiayaan berdasarkan akad kerjasama antara dua belah pihak atau lebih untuk suatu usaha tertentu. Dimana masing-masing pihak memberikan kontribusi modal dengan ketentuan keuntungan dan kerugian ditanggung bersama sesuai dengan kesepakatan. ${ }^{23}$

\section{Akad Mudharabah}

Mudharabah adalah akad kerja sama antara dua orang dimana pihak pertama memberikan modal dan pihak kedua sebagai pengelola, laba terbagi sesuai nisbah bagi hasil dan sesuai kesepakatan diawal, sedangkan kerugian ditanggung oleh pemilik dana. ${ }^{24}$

Mudharabah adalah akad kerjasama usaha antara dua pihak dimana pihak pertama (pemilik dana) menyediakan seluruh dana, sedangkan pihak kedua (pengelola dana) bertindak selaku pengelola, dan keuntungan dibagi sesuai kesepakatn sedangkan kerugian ditanggung oleh pemilik dana. ${ }^{25}$

\subsection{Pembiayaan Bermasalah (NPF)}

Pembiayaan bermasalah (NPF) adalah penyaluran dana yang dilakukan oleh pihak bank syariah dimana pelaksaaan pembayaran pembiayaan

${ }^{22}$ Nur Huda, Fitri Fajri, The Analysis ..., h. 95.

${ }^{23}$ Ikit, Manajemen..., , h. 115.

${ }^{24}$ Ana Fitriyani dkk, "Pengaruh Pembiayaan Murabahah, Mudharabah dan Non Performing Financing (NPF) terhadap Profitabilitas Bank Umum Syariah terdaftar di Bank Indonesia Tahun 20142017’. Jurnal Widya Ganeswara. Vol. 28, No 1, 2019 ISSN: 0853-0521, h. 3.

${ }^{25}$ Ikit, Manajemen ..., h. 108. nasabah terjadi pembiayaan tidak lancar, pembiayaan debiturnya tidak memenuhi persyaratan yang dijanjikan, dan pembiayaan dimana jadwal angsurannya tidak tepat. Sehingga berdampak negatif bagi kedua belah pihak (nasabah dan bank).

Non Performinh Financing (NPF) atau pembiayaan bermasalah secara luas terdefinisikan sebagai pembiayaan dalam pembayaran yang tidak lancar dan tidak mencukupi kewajiban minimal yang ditetapkan sampai dengan pembiayaan yang sulit dilunasi bahkan tidak dapat ditagih.

Tugas Bank Indonesia (BI) antara lain adalah mempertahankan agar sistem perbankan yang sehat serta dapat dipercaya dengan tujuan menjaga perekonomian. Dengan begitu, BI sebagai Bank Sentral dan sebagai pengawas perbankan di Indonesia memberikan ketentuan ukuran penilaian tingkat kesehatan suatu Bank. Salah satu ketentuan BI mengenai NPF adalah Bank-Bank harus memiliki NPF kurang dari 5\%.26 NPF dapat dinyatakan dalam rumus sebagai berikut: ${ }^{27}$

$$
\mathrm{NPF}=\frac{\text { Pembiayaan }(\mathrm{K}, \mathrm{L}, \mathrm{D}, \mathrm{M})}{\text { Total Pembiayaan }} \times 100 \%
$$

\section{Faktor-faktor Penyebab Pembiayaan Bermasalah}

Secara umum, faktor-faktor yang mempengaruhi dan menyebabkan terjadinya pembiayaan bermasalah adalah sebagai berikut:

${ }^{26}$ Maidalena, "Analisis Faktor Non Performing Financing (NPF) pada Industri Perbankan Syariah", Jurnal Human Falah: Vol. 1, No. 1. Januari-Juli 2014, h. 132.

27 Pramudya Yuli Astuti, Analisis Rasio Keuangan yang Mempengaruhi Market Share pada Bank Muamalat Indonesia Periode 2014-2018, Skripsi, UIN Waliongo Semarang, h. 69. 
a. Faktor dari Nasabah

Tidak semua nasabah mempunyai itikad baik pada saat mengajukan pembiayaan ataupun pada saat pembiayaan yang diberikan sedang berjalan. Itikad yang tidak baik inilah memang sulit untuk diketahui dan dianalisis oleh pihak Bank, karena demikian menyangkut soal moral ataupun akhlak dari nasabah.

b. Faktor dari Bank

Berbagai peraturan perundangundangan yang menajdi tolak ukur bagi bank dalam melakukan kegiatan usaha penyaluran dana. Seperti ketentuan mengenai batas maksimum pemberian kresi atau BMPK, rasio pemberian kredit diliat dari nilai jaminan yang diberikan dan berbagai aturan lainnya.

c. Faktor dari Luar Nasabah dan Bank (Ekstern)

Pembiayaan bermasalah bisa terjadi adanya dari pihak luar debitur maupun kreditur. Faktor ini terjadi karena krisis moneter, kerusuhan massal, terjadinya bencana alam seperti gempa bumi, banjir, kebakaran dan kejadian-kejadian lainnya. Pengaruh kondisi ekonomi global juga bisa berdampak terhadap perputaran perekonomian dalam negeri, yaitu naiknya harga minyak dunia yang berimbas kepada berhentinya kegiatan usaha para pengusaha sehingga keadaan perekonomian enjadi lesu karena menurunnya daya beli masyarakat atau konsumen.

Adapun kriteria kesehatan pada Bank Syariah yang ditetapkan oleh Otoritas Jasa Keuangan sebagai berikut:
Kriteria penilaian Non Performing Financing

\begin{tabular}{|c|l|c|}
\hline Peringkat & $\begin{array}{c}\text { Nilai NPF } \\
\text { Predikat }\end{array}$ & Predikat \\
\hline 1 & $\begin{array}{l}\text { Peringkat } \\
\text { Komposit } 1 \\
(\text { PK-1) }\end{array}$ & $\begin{array}{c}\text { Sangat } \\
\text { Sehat }\end{array}$ \\
\hline 2 & $\begin{array}{l}\text { Peringkat } \\
\text { Komposit } 2 \\
\text { (PK-2) }\end{array}$ & Sehat \\
\hline 3 & $\begin{array}{l}\text { Peringkat } \\
\text { Komposit } 3 \\
\text { (PK-3) }\end{array}$ & $\begin{array}{c}\text { Cukup } \\
\text { Sehat }\end{array}$ \\
\hline 4 & $\begin{array}{l}\text { Peringkat } \\
\text { Komposit } 4 \\
\text { (PK-4) }\end{array}$ & $\begin{array}{c}\text { Kurang } \\
\text { Sehat }\end{array}$ \\
\hline 5 & $\begin{array}{l}\text { Peringkat } \\
\text { Komposit 5 } \\
(\text { PK-5) }\end{array}$ & $\begin{array}{c}\text { Tidak } \\
\text { Sehat }\end{array}$ \\
\hline
\end{tabular}

\subsection{Kinerja Keuangan}

Kinerja keuangan bank adalah gambaran kondisi keuangan bank pada suatu periode tertentu baik menyangkut aspek penghimpunan atau penyaluran dana yang biasanya diukur dengan indikator kecukupan modal, likuditas dan profitabilitas.

Kinerja keuangan merupakan salah satu faktor penting yang menunjukkan efektifitas dan efisiensi dalam perbankan syariah untuk mencapai tujuan. Kinerja keuangan bank mencerminkan kemampuan operasional dalam suatu bank. Penurunan kinerja secara terus menerus dapat menyebabkan bank berada dalam keadaan yang tidak baik bahkan dapat beresiko mengalami kebangkrutan dan jika tidak terselesaikan dengan cepat, akan berdampak besar pada bank 
tersebut dengan hilangnya kepercayaan dari nasabah. ${ }^{28}$

Perhitungan yang digunakan untuk mengukur tingkat profitabilitas adalah menggunakan Return On Asset (ROA). ${ }^{29}$ Semakin besar ROA, semakin besar pula tingkat keuntungan yang dicapai oleh perusahaan tersebut dari segi penggunaan asset. ${ }^{30}$ ROA berfungsi sebagai pengukur efektivitas perusahaan dan menghasilkan laba dengan memanfaatkan efektivitas perusahaan melalui pengoperasian aset yang dimiliki semakin besar ROA yang dimiliki perusahaan maka semakin efisien penggunaan asset sehingga laba yang didapat semakin besar. Laba yang besar akan menarik investor dikarenakan perusahaan memiliki tingkat pengembalian investasi yang semakin tinggi. ${ }^{31}$ Perhitungan ROA berdasarkan Surat Edaran Bank Indonesia Nomor 12/11/DPNP tanggal 31 Maret 2010, diperoleh dengan rumus: ${ }^{32}$

Return On Asset $=\underline{\text { Laba } \text { sebelum pajak }} \mathbf{x}$ $100 \%$

Total aset

Kriteria tingkat penilaian profitabilitas

\begin{tabular}{|c|c|}
\hline Rasio & Kategori \\
\hline ROA $\geq 1,5 \%$ & Sangat sehat \\
\hline $1,25 \% \leq \mathrm{ROA} \leq$ & Sehat \\
$1,5 \%$ & \\
\hline
\end{tabular}

${ }^{28}$ Meri Diana Puteri, Analisis Pengukuran Kinerja Keuangan Bank Umum Syariah di Indonesia Menggunakan Metode Sharia Conformity and Profitability (SCnP) Model, Skripsi, 2018, h. 39.

${ }^{29}$ Achmad Syaiful Nizar, Moch. Khoirul Anwar, Pengaruh ..., h. 130.

30 Pramudya Yuli Astuti, Analisis Rasio Keuangan yang Mempengaruhi Market Share pada Bank Muamalat Indonesia Periode 2014-2018, Skripsi, h. 42.

${ }^{31}$ Sheila Mega Cahyani, Pengaruh .., h. 3.

${ }^{32}$ Yuyun Agustina, Ekonomi dan Bisnis ...,

\begin{tabular}{|c|c|}
\hline $\begin{array}{c}0,5 \% \leq \mathrm{ROA} \leq \\
1,25 \%\end{array}$ & Cukup sehat \\
\hline $0 \leq \mathrm{ROA} \leq 0,5 \%$ & Kurang sehat \\
\hline $\mathrm{ROA} \leq 0$ & Tidak sehat \\
\hline
\end{tabular}

\section{METHODOLOGY}

Penelitian merupakan penelitian kepustakaan (library research) dengan menggunakan metode pendekatan kuantitatif, karena data yang diperoleh nantinya berupa angka. Dari angka yang diperoleh akan dianalisis lebih lanjut dalam analisis data. Jenis data penelitian ini adalah data sekunder yang bersifat tem series. Penelitian ini terdiri atas empat variabel, yaitu pembiayan jual beli, pembiayaan bagi hasil dan pembiayaan bermasalah (Non Performing Financing/NPF) sebagai variabel bebas (independent) dan Kinerja Keuangan (ROA) sebagai variabel terikat (dependen).

Adapun sumber data yang digunakan dalam penelitian ini bersumber dari Laporan Publikasi Otoritas Jasa Keuangan (OJK) dari website resmi www.ojk.go.id dan Laporan Keuangan Bank BRI Syariah melalui website resmi www.brisyariah.co.id.

Adapun populasi dalam penelitian ini yaitu pada pembiayaan jual beli, pembiayaan bagi hasil, pembiayaan brmasalah (NPF) dan kinerja keuangan (ROA) pada laporan keuangan yang terdapat pada Bank BRI Syariah. Sedangkan Teknik dalam pengambilan sampel ini penulis menggunakan teknik purposive sampling. Purposive sampling adalah teknik penentuan sampel dengan pertimbangan tertentu. Sampel data penelitian ini yaitu meliputi pembiayaan jual beli, pembiayaan bagi hasil, 
pembiayaan bermasalah (NPF) dan kinerja keuangan (ROA) pada Bank BRI Syariah periode Maret 2009 - Desember 2019.

Pada penelitian ini pengumpulan data menggunakan metode dokumentasi. Pada penelitian ini data yang diambil yaitu pembiayaan jual beli, pembiayaan bagi hasil, dan pembiayaan bermasalah (NPF) dan juga ROA periode maret 2009 - desember 2019. Sedangkan teknik analisis data merupakan cara untuk menganalisa data yang diperoleh dengan tujuan untuk menguji rumusan masalah melalui uji validitas, uji realibiilitas, uji asumsi klasik, uji regresi berganda dan uji hipotesis.

\section{HASIL DAN PEMBAHASAN}

\subsection{Gambar Umum Objek Penelitian}

Penelitian ini menganalisis pengaruh Pembiayaan Jual Beli, Bagi Hasil, dan Pembiayaan Bermasalah terhadap Kinerja Keuangan pada Bank BRI Syariah periode 2009-2019. Objek penelitian yaitu Bank BRI Syariah dengan data laporan keuangan triwulan untuk periode tahun 2009-2019. Berikut ini sejarah singkat dari Bank BRI Syariah yang merupakan sampel dari penelitian ini.

PT Bank BRI Syariah Tbk berdiri tidak lepas dari akuisisi oleh PT Bank Rakyat Indonesia (Persero) Tbk terhadap Bank Jasa Arta pada Desember 2007. Setelah mendapatkan izin usaha dari Bank Indonesia melalui surat No. 10/67/KEP.GBI/DPG/2008 pada 16 Oktober 2008 BRISyariah resmi beroperasi pada 17 November 2008 dengan nama Bank BRISyariah dan seluruh kegiatan usahanya berdasarkan prinsip syariah Islam.
Pada tanggal 19 Desember 2008, Unit Usaha Syariah PT Bank Rakyat Indonesia (Persero) melebur ke dalam PT Bank BRI Syariah. Proses spin off tersebut berlaku efektif pada tanggal 1 Januari 2009 dengan penandatangan yang dilakukan oleh Sofyan Basir selaku Direktur Utama PR Bank Rakyat Inodonesia (Persero) Tbk dan Ventje Rahardjo selaku Direktur Utama PT Bank BRIsyariah.

Pada tahun 2018, BRI Syariah mengambil langkah lebih pasti lagi dengan melaksanakan Intial Public Offering pada tanggal 9 Mei 2018 di Bursa Efek Indonesia. IPO ini menjadikan BRI Syariah sebagai anak usaha BUMN di bidang syariah yang pertama melaksanakan penawaran umum sahan perdana.

Bank BRI Syariah juga terus mengembangkan teknologi informasi untuk penguatan digital banking demi memberikan kemudahan dan kenyamanan kepada nasabah. Hal itu dilakukan dengan peningkatan produk yang sudah ada melalui layanan integrasi dari internet banking BRIS dan mobile banking andalan Bank BRI Syariah yang diberi nama BRIS Online. Aplikasi ini memudahkan nasabah Bank BRI Syariah untuk memanfaatkan layanan perbankan BRI Syariah tanpa harus mendatangi kantor Bank BRI Syariah.

\subsection{Hasil Penelitian}

Hasil Pengujian Uji t

Untuk variable pembiayaan Jual Beli (X1) menunjukkan nilai thitung sebesar $(-0,428)<t_{\text {tabel }}$ sebesar $(2,701)$ $(\mathrm{Df}=\mathrm{n}-\mathrm{k})$ dan nilai sig. Sebesar $(0,671)$ $>(0,05)$. Maka $\mathrm{H}_{0}$ diterima dan $\mathrm{Ha}$ ditolak. Sehingga dapat disimpulkan bahwa Pembiayaan Jual Beli tidak 
berpengaruh terhadap kinerja keuangan pada bank BRI Syariah pada tahun 20092019.

Untuk variable Pembiayaan Bagi Hasil (X2) menunjukkan nilai thitung sebesar $(-0.902)<t_{\text {tabel }}$ sebesar $(2,701)$ $(\mathrm{Df}=\mathrm{n}-\mathrm{k})$ dan nilai sig. Sebesar $(0,372)$ $>(0,05)$. Maka $\mathrm{H}_{0}$ diterima dan $\mathrm{Ha}$ ditolak. Sehingga dapat disimpulkan bahwa pembiayaan bagi hasil tidak berpengaruh terhadap kinerja keuangan pada bank BRI Syariah pada tahun 20092019.

Untuk variabel Pembiayaan Bermasalah (X3) menunjukkan nilai thitung sebesar $(3,513) t_{\text {tabel }}$ sebesar $(2,701)(\mathrm{Df}=\mathrm{n}-\mathrm{k})$ dan nilai sig. $(0.001)<$ $(0,05)$. Maka $\mathrm{H}_{0}$ ditolak dan $\mathrm{H}_{\mathrm{a}}$ diterima. Sehingga dapat disimpulkan bahwa Pembiayaan Bermasalah berpengaruh terhadap kinerja keuangan pada bank BRI Syariah pada tahun 2009-2019.

Berdasarkan uji koefisien determinasi $\left(\mathrm{R}^{2}\right)$ atau Model Summary didapatkan bahwa nilai Adjusted $\mathrm{R}^{2}$ adalah sebesar 0,302 atau 30,2\%. Dapat disimpulkan bahwa pengaruh pembiayaan jual beli, pembiayaan bagi hasil dan pembiayaan bermasalah terhadap kinerja keuangan sebesar $30,2 \%$. Sedangkan sisanya sebesar $69,8 \%$ $(100 \% \quad-30,8 \%) \quad$ dipengaruhi oleh variabel-variabel lain yang tidak dimasukkan ke dalam penelitian ini.

Regresi Linear Berganda

Berdasarkan hasil analisis regresi linear berganda diperoleh hasil yang dapat dilihat pada tabel berikut :

\begin{tabular}{|l|l|l|l|}
\hline \multicolumn{1}{|c|}{ Faktor } & $\begin{array}{c}\text { Koefisien } \\
\text { Regresi }\end{array}$ & $\begin{array}{c}\text { t- } \\
\text { hitung }\end{array}$ & Sig \\
\hline Constanta & 0.425 & 1.125 & 0.267 \\
\hline $\begin{array}{l}\text { Pembiayaan Jual } \\
\text { Beli }\end{array}$ & -2.724 & -0.428 & 0.671 \\
\hline
\end{tabular}

\begin{tabular}{|l|l|l|l|}
\hline $\begin{array}{l}\text { Pembiayaan bagi } \\
\text { hasil }\end{array}$ & -7.421 & -0.902 & 0.372 \\
\hline $\begin{array}{l}\text { Pembiayaan } \\
\text { bermasalah }\end{array}$ & 0.220 & 3.513 & 0.001 \\
\hline
\end{tabular}

Berdasarkan tabel uji data regresi linear berganda diatas, maka bentuk persamaan regresi dari model tersebut adalah sebagai berikut:

$$
\begin{gathered}
\mathrm{Y}=0,402-2,724 \mathrm{E}-8 \mathrm{X}_{1}-7,421 \mathrm{E}-8 \mathrm{X}_{2}+ \\
0,220 \mathrm{X}_{3}
\end{gathered}
$$

Berdasarkan persamaan regresi diatas menunjukkan nilai konstanta sebesar 0,402 menyatakan bahwa jika variabel Pembiayaan Jual Beli, Pembiayaan Bagi Hasil dan Pembiayaan Bermasalah dianggap konstan, maka rata-rata ROA adalah sebesar 0,402. Selain itu, dari hasil tersebut juga menunjukan bahwa:

Koefisien regresi Pembiayaan Jual Beli sebesar -2,724E-8 menyatakan bahwa setiap peningkatan sebesar $1 \%$ nilai Pembiayaan Jual Beli, maka secara rata-rata ROA akan mengalami peningkatan sebesar $-2,724 \mathrm{E}-8 \%$

Koefisien regresi Pembiayaan Bagi Hasil sebesar -7,421E-8 menyatakan bahwa setiap peningkatan sebesar 1\% nilai Pembiayaan Bagi Hasil, maka secara rata-rata, ROA akan mengalami peningkatan sebesar 7,421E-8 \%.

Koefisien regresi Pembiayaan Bermasalah sebesar 0,220 menyatakan bahwa setiap peningkatan sebesar $1 \%$ nilai Pembiayaan Bermasalah, maka secara rata-rata, ROA akan mengalami peningkatan sebesar $0,220 \%$.

\subsection{Pembahasan Hasil Penelitian \\ Pengaruh Pembiayaan Jual Beli Terhadap Kinerja Keuangan Bank BRI Syariah}


Hasil penelitian ini menunjukkan bahwa pembiayaan jual beli memiliki nilai thitung sebesar $(-0,428)<t_{\text {tabel }}$ sebesar $(2,701)(\mathrm{Df}=\mathrm{n}-\mathrm{k})$ dan nilai sig. Sebesar $(0,671)>(0,05)$. Maka $\mathrm{H}_{0}$ diterima dan Ha ditolak. Sehingga dapat disimpulkan bahwa Pembiayaan jual beli terbukti tidak berpengaruh terhadap kinerja keuangan yang diukur dengan Retrun On Asset (ROA) pada bank BRI Syariah.

Pembiayaan jual beli terdiri dari pembiayaan murabahah dan pembiayaan istishna. Pembiayaan yang dominan digunakan pada pembiayaan jual beli adalah pembiayaan murabahah kemudian disusul pembiayaan istishna. Penyebab tidak pengaruhnya bisa terdapat pada pendapatan yang diperoleh bank syariah pada pembiayaan jual beli berupa margin keuntungan dimana termasuk harga jual. Dalam pelunasannya, pihak nasabah melakukan pembayaran dengan cara bertahap atau mengangsur. Dengan begitu, bank syariah dapat menaikkan pendapatan dengan cara menaikkan margin keuntungan. Dimana semakin lama jangka waktu pembayaran, maka margin yang didapat semakin besar. Tetapi keuntungan yang diterima oleh bank syariah secara bertahap. ${ }^{33}$ Dan apabila pelunasan dipercepat, maka pendapatan yang diterima oleh bank syariah kurang maksimal.

Penelitian ini sejalan dengan hasil penelitian yang dilakukan oleh Achmad Syaiful Nizar dengan judul pembiayaan jual beli, pembiayaan bagi hasil dan

33 Musyahidah, S., Prasanti, N. M., Hasanah, U., \& Ferdiawan, F. (2020). Tinjauan Ekonomi Islam Pada Prospek Industri Daur Ulang Sampah Plastik Jurnal Ilmu Ekonomi dan Bisnis Islam, 2(1), 74-89.
Intellectual Capital terhadap kinerja keuangan bank syariah bahwa pembiayaan jual beli tidak berpengaruh terhadap kinerja keuangan bank syariah. Tetapi penelitian ini tidak sejalan dengan penelitian yang dilakukan oleh Ian Azhar, Arim dengan judul pengaruh pembiayaan jual beli, bagi hasil, dan Non Performing Finance terhadap profitabilitas bank umum syariah bahwa pembiayaan jual beli berpengaruh terhadap profitabilitas yang diproksikan ROA.

Pengaruh Pembiayaan Bagi Hasil Terhadap Kinerja Keuangan Bank BRI Syariah

Hasil penelitian ini menunjukkan bahwa pembiayaan bagi hasil memiliki nilai thitung sebesar $(-0.902)<t_{\text {tabel }}$ sebesar $(2,701)(\mathrm{Df}=\mathrm{n}-\mathrm{k})$ dan nilai sig. Sebesar $(0,372)>(0,05)$. Maka $\mathrm{H}_{0}$ diterima dan Ha ditolak. Sehingga dapat disimpulkan bahwa pembiayaan bagi hasil tidak berpengaruh terhadap kinerja keuangan pada bank BRI Syariah.

Pembiayaan bagi hasil merupakan salah satu dari pembiayaan yang disediakan oleh Bank Umum Syariah. Pembiayaan bagi hasil terdiri dari pembiayaan mudharabah dan pembiayaan musyarakah. Penyebab dari hubungan negatif yang dihasilkan antara pembiayaan bagi hasil terhadap ROA yaitu pihak nasabah menerima pembiayaan bagi hasil dari pihak bank, dimana pihak nasabah belum tentu mengembalikan dana tersebut pada tahun yang sama. Artinya pelunasan pembiayaan yang dilakukan nasabah pada tahun-tahun berikutnya. Hal ini akan berdampak hilangnya kesempatan bank syariah menambah total perolehan laba melalui margin bagi hasil, sehingga laba yang diterima pihak bank syariah 
pada tahun pinjaman yang diberikan akan berkurang.

Penelitian ini sejalan dengan hasil penelitian yang dilakukan oleh Yuyun Agustina dengan judul pengaruh pembiayaan jual beli, pembiayaan bagi hasil, dan Rasio Non Performing Financing (NPF) terhadap profitabilitas (ROA) Bank Umum Syariah di Indonesia bahwa pembiayaan bagi hasil tidak berpengaruh terhadap ROA pada Bank Umum Syariah di Indonesia. Tetapi penelitian ini tidak sejalan dengan penelitian yang dilakukan oleh Ian Azhar, Arim dengan judul pengaruh pembiayaan jual beli, bagi hasil, dan Non Performing Finance terhadap profitabilitas bank umum syariah bahwa pembiayaan bagi hasil berpengaruh terhadap profitabilitas yang diproksikan ROA.

Pengaruh Pembiayaan Bermasalah Terhadap Kinerja Keuangan Bank BRI Syariah

Hasil penelitian ini menunjukkan bahwa pembiayaan bermasalah memiliki nilai thitung sebesar $(3,513)$ $t_{\text {tabel }}$ sebesar $(2,701) \quad(\mathrm{Df}=\mathrm{n}-\mathrm{k})$ dan nilai sig. $(0.001)<(0,05)$. Maka $\mathrm{H}_{0}$ ditolak dan $\mathrm{H}_{\mathrm{a}}$ diterima. Sehingga dapat disimpulkan bahwa Pembiayaan Bermasalah berpengaruh terhadap kinerja keuangan pada bank BRI Syariah.

Pembiayaan bermasalah atau NPF merupakan rasio gagal bayar dalam penyaluran kredit. Sehingga semakin tinggi nilai NPF maka akan berakibat buruk pada perbankan. Begitu sebaliknya, semakin rendah nilai NPF maka akan semakin baik bagi kinerja perbankan. NPF berpengaruh positif terhadap ROA terbukti pada tahun 2019 bahwa nilai NPF menurun dari tahun sebelumnya sehingga kinerja perbankan semakin baik.

Penelitian ini sejalan dengan hasil penelitian yang dilakukan oleh Nur Kholis dan Lintang Kurniawan dengan judul pengaruh pembiayaan bagi hasil, Non Performing Financing (NPF) dan biaya operasional (BOPO) terhadap Return On Asset (ROA) pada Bank Umum Syariah bahwa Non Performing Financing (NPF) atau pembiayaan bermasalah berpengaruh terhadap ROA. Tetapi penelitian ini tidak sejalan dengan penelitian yang dilakukan oleh Ana Fitriyani, dkk dengan judul pengaruh pembiayaan Murabahah, Mudharabah dan Non Performing Financing (NPF) atau pembiayaan bermasalah terhadap profitabilitas Bank Umum Syariah bahwa Non Performing Financing (NPF) atau pembiayan bermasalah tidak berpengaruh terhadap profitabilias (ROA) Bank Umum Syariah.

\section{KESIMPULAN DAN SARAN \\ 5.1 Kesimpulan}

Berdasarkan hasil penelitian dalam pembahasan yang telah diuraikan pada bab sebelumnya, maka penulis dapat mengambil kesimpulan bawah :

1. Pembiayaan jual beli tidak berpengaruh terhadap kinerja keuangan dengan nilai thitung sebesar $(-0,428)$ dan nilai signifikan Sebesar $(0,671)>(0,05)$. Hal ini menunjukkan bahwa apabila terjadi penurunan pada pembiayaan jual beli maka tidak ada pengaruhnya terhadap kinerja keuangan. Apabila ada pengaruh, pembiayaan jual beli mempunyai pengaruh yang sangat kecil terhadap kinerja keuangan Bank BRI Syariah.

2. Pembiayaan bagi hasil tidak berpengaruh terhadap kinerja 
keuangan dengan nilai thitung sebesar $(-0.902)$ dan nilai signifikan Sebesar $(0,372)>(0,05)$. Hal ini menunjukkan bahwa apabila terjadi penurunan pada pembiayaan bagi hasil maka tidak ada pengaruhnya terhadap kinerja keuangan. Apabila ada pengaruh, pembiayaan bagi hasil mempunyai pengaruh yang sangat kecil terhadap kinerja keuangan Bank BRI Syariah.

3. Pembiayaan bermasalah (NPF) memiliki pengaruh terhadap kinerja keuangan dengan nilai thitung sebesar $(3,513)$ dan nilai signfikasi $(0.001)<$ $(0,05)$. Hal ini menunjukkan bahwa semakin tinggi nilai pembiayaan bermasalah (NPF) maka semakin luas kinerja keuangan yang diperoleh Bank BRI Syariah.

\subsection{Saran}

Berdasarkan kesimpulan yang ada maka penulis dapat memberikan saransebagai berikut:

1. Bagi Bank BRI Syariah

Pihak Bank BRI Syariah harus terus meningkatkan penyaluran pembiayaan khususnya pembiayaan jual beli dan pembiayaan bagi hasil. Pihak bank harus memperkenalkan dan menjelaskan pembiayaan kepada nasabah yang kurang paham tentang pembiayaan-pembiayaan yang ada. Hal ini dapat menarik minat bagi nasabah dalam melakukan pembiayaan di Bank BRI Syariah.

2. Bagi investor

Dari hasil penelitian bisa dijadikan acuan bagi investor supaya bisa lebih cermat dalam memilih pembiayaan yang disediakan oleh Bank BRI Syariah baik itu dari segi prinsip jual beli maupun prinsip bagi hasil sebelum melakukan penanaman modal atau menggunakan pembiayaan pada Bank BRI Syariah tersebut.

3. Bagi Akademis

Hasil penelitian ini diharapkan untuk dijadikan tambahan referensi kepada penulis maupun penelitian selanjutnya yang tertarik untuk meneliti dengan topik yang sama yaitu pembiayaan jual beli, bagi hasil dan pembiayaan bermasalah terhadap kinerja keuangan. Diharapkan juga dijadikan sebagai tambahan pengetahuan, informasi dan wawasan terkait dengan variabelvariabel seperti pembiayaan jual beli, bagi hasil, pembiayaan bermasalah dan kinerja keuangan.

4. Bagi peneliti selanjutnya

Bagi peneliti selanjutnya, penulis menyarankan sebaiknya menambah variabel penelitian seperti BOPO, NOM. FDR, NIM, LDR ataupun fatorfaktor lainnya yang dapat mempengaruh kinerja keuangan.

\section{DAFTAR PUSTAKA}

Agustina, Yuyun. "Pengaruh Pembiayaan Jual Beli, Pembiayaan Bagi Hasil dan Rasio Non Performing Financing (NPF) Terhadap Profitabilitas (ROA) Bank Umum Syariah di Indonesia", Jurnal Yuyun Agustina-Ekonomi dan Bisnis, UMS 2013.

A.Karim, Adiwarman. Bank Islam, Analisis Fikih dan Keuangan, Edisi

4, Jakarta: PT Raja Grafindo Persada, 2011.

Alfie, Atieq Amjadallah dan maftuchatul Khanifah, Pembiayaan Natural Certainty Contract (NCC) dan Pembiayaan Natural Uncertainty Contract (NUC) Pada Profitabilitas 
Bank Umum Syariah, disusun oleh mahasiswa Fakultas

Ekonomi Universitas Wahid Hasyim, 2017.

Almunawwaroh, Medina dan Rina Marlina, Pengaruh CAR, NPF dan FDR terhadap Profitabilitas Bank Syariah di Indonesia, Jurnal Ekonomi dan Keuangan Syariah, Vol. 2, No. 1 Januari 2018.

Alwi, Ahmad. Pengaruh Capicity dan Capital Sebagai Prinsip Pembiayaan Terhadap Keputusan Menjadi Nasabah Pembiayaan Mudharabah di Bank Syariah Mandiri Cabang Semarang, Skripsi, Semarang UIN Walisongo Semarang, 2015.

Amirullah, Populasi dan Sampel (Pemahaman, Jenis dan teknik, Malang: Bayumedia Publishing.

Annisa, Ayu dkk, Pengaruh Kinerja Keuangan terhadap Simoanan Dana Pihak Ketiga Melalui Nisbah Bagi Hasil (Studi Kasus Bank Umum Syariah di Indonesia Peride 2012-2015, Jurnal AKUNABEL. ISSN Print:0216-7743 ISSN Online: 2528-1135, Vol. 14, No.2 2017.

Antonio, Muhammad Syafi'i, Bank Syariah dari Teori ke Praktik Jakarta: Gema Insani, 2001.

Ascaya, Diana Yumanita, Bank Syariah:Gambar

Jakarta:PPSK Umum, INDONESIA,2005.

Asiyah, Binti Nur. Manajemen Pembiayaan Bank Syariah, Yogyakarta: KALIMEDIA, 2015. cet.1.

Azhar, Ian, Arim. "Pengaruh Pembiayaan Jual Beli, Pembiayaan Bagi hasil, dan
Non Performing Financing Terhadap Profitabilitas (Studi Kasus Pada Bank Umum Syariah di Indonesia Periode 2012-2014)", Jurnal Aset (Akuntansi Riset) Vol 8, No. 1, 2016.

Hidayat, Rahmat. Efisiensi Perbankan Syariah Teori dan Praktik, Bekasi: Gramata Publishing, 2014.

https://nasional.kompas.com/read/200 8/11/03/09230232/istilah.perba nkan.syariah?page $=$ all

Huda,Nur dan Fitri Fajri, "The Analysis Of Musyarakah Contract Sharing System Implementationin BPRS Saka Dana Mulia Kudus", $A L$ ARBAH:Journal of Islamic Financing and Banking. Vol. 1 No. 1 (2019), 95-106; DOI: 10.21580/al-arbah.2019.1.1.4159.

Ikit, Manajemen Dana Bank Syariah, Yogyakarta: Penerbit Gava Media, 2018, cet 1 .

Fatwa Dewan Syariah Nasional Nomor 05/DSN-MUI/IV/2000 Tentang Jual Beli Salam.

Fatwa Dewan Syariah Nasional Nomor 07/DSN-MUI/IV/2000 Tentang Pembiayaan Mudharabah (Qiradh).

Fatwa Dewan Syariah Nasional Nomor 08/DSN-MUI/IV/2000 Tentang Pembiayaan Musyarakah.

Fitriyani, Ana, dkk. "Pengaruh Pembiayaan Murabahah, Mudharabah dan Non Performing Financing (NPF) terhadap Profitabilitas Bank Umum Syariah terdaftar di Bank Indonesia Tahun 2014-2017", Jurnal Widya Ganeswara. Vol. 28, No 1, 2019 ISSN: 0853-0521. 
Maidalena, "Analisis Faktor Non Performing Financing (NPF) pada Industri Perbankan Syariah", Jurnal Human Falah: Vol. 1, No. 1. Januari-Juli 2014.

Malarangan, H., Irfan, I., Haekal, A., \& Istiqamah, R. (2020). Analisis Tanggung Jawab Pegadaian Syariah Palu Plaza Terhadap Barang Jaminan yang Hilang dan Rusak Jurnal Ilmu Ekonomi dan Bisnis Islam, 2(1), 15-35.

Musyahidah, S., Prasanti, N. M., Hasanah, U., \& Ferdiawan, F. (2020). Tinjauan Ekonomi Islam Pada Prospek Industri Daur Ulang Sampah Plastik Jurnal Ilmu Ekonomi dan Bisnis Islam, 2(1), 7489.

Nachrowi, Nachrowi D Dan Hardinus Usman, Pendekatan Ekonomtrika Untuk Analisis Ekonomi Dan Keuangan, Jakarta: Lembaga Penerbit Fakultas Ekonomi Universitas Indonesia, 2006.

Nizar, Achmad Syaiful, Moch. Khoirul Anwar, "Pengaruh Pembiayaan Jual Beli, Pembiayaan Bagi Hasil dan Intellectual Capital Terhadap Kinerja Keuangan Syariah", Jurnal Akrual 6 (2) (2015): 127-143 e-ISSN: 25026380.

Nurdin, N., Pettalongi, S. S., \& Yusuf, K. (2018, 27-28 Sept. 2018). Knowledge Management Model in Syariah Banking. Paper presented at the 2018 5th International Conference on Information Technology, Computer, and Electrical Engineering (ICITACEE).

Nurdin, N., \& Yusuf, K. (2020). Knowledge management lifecycle in Islamic bank: the case of syariah banks in Indonesia.
International Journal of Knowledge Management Studies, 11(1), 59-80. doi: 10.1504/ijkms.2020.105073

Purnomo, Rochmat Aldy Analisis Statistik Ekonomi dan Bisnis dengan SPSS, Ponorogo: CV Gawe Group, 2016.

Puteri, Meri Diana. Analisis Pengukuran Kinerja Keuangan Bank Umum Syariah di Indonesia Menggunakan Metode Sharia Conformity and Profitability (SCnP) Model, Skripsi, 2018.

Putri Friska Larasati, Pengaruh Pembiayaan Mudarabah Terhadap Profitabiltas Bank Syariah, Jurnal Pendidikan Akuntansi dan Keuangan, Vol. 5, No. 1, (Januari-Juni), 2017.

Priyastama, Romi. Buku Sakti SPSS, Bantul: Start Up, 2017.

Riyadi, Slamet dan Agung Yulianto, Pengaruh Pembiayaan Bagi Hasil, Pembiayaan Jual Beli, Financing To Deposit Ratio (FDR) dan Non Performing Financing (NPF) terhadap Profitabilitas Bank Umum Syariah di Indonesia, Accounting Analysis Journal 3 (4) (2014).

Salinan Peraturan Otoritas Jasa Keuangan Nomor 2/POJK.03/2016 Tentang Pengembangan Jaringan Kantor Perbankan Syariah dalam Rangka Stimulus Perekonomian Nasional Bagi Bank.

Sam, L.H.M. Ichwan dkk, Himpunan Fatwa Dewan Syariah Nasional, Jakarta: P.T. Intermasa, 2003.

Samidi, "Pengaruh Stategi Pembelajaran Student Team Heroic Leadership terhadap Kreativitas Belajar Matematika pada Siswa 
SMP Negeri 29 Medan T.P 2013/2014", Jurnal EduTech Vol. 1 No. 1 Maret 2015.

Sandy P, Dewi. Pengaruh Pembiayaan Bagi Hasil, Pembiayaan Jual Beli, dan Financing To Deposit Ratio terhadap Profitabilitas Pada Bank Umum Syariah di Indonesia, Artikel Ilmiah 2014.

Sangaji, Etta Mamang dan Sopiah, Metodologi Penelitian Pendekatan Praktis dalam Penelitian, Yogyakarta: CV Andi Offset, 2014.

Sarjono, Haryadi dan Winda Julianita, SPSS VS LISREL, Jakarta: Salemba Empat.

Setia Budi Wilardjo, Setia. "Pengertian, Peranan dan Perkembangan Bank Syariah di Indonesia", Jurnal VALUE ADDED, Vol. 2,
No. 1, September 2004-Maret 2005, Hlm. 2.

Suharso dkk. Kamus Besar Bahasa Indonesia Edisi Lux, Semarang: CV. Widya Karya.

Sunyoto, Danang. Analisis Vitalitas dan Asumsi Klasik, Yogyakarta: Gava Media, 2012.

Supriyadi, Ahmad. "Sistem Pembiayaan Berdasarkan Prinsip Syariah", Jurnal Al-Mawardi Edisi X Tahun 2003.

Sutojo, Siswanto. Menangani Kredit Bermasalah Konsep, Teknik dan Kasus, Jakarta: Damar Mulia Pustaka, 2000

Winarsih, Wiwin Pembiayaan Dana Pihak Ketiga pada pertumbuhan Laba Bersih Bank BNI Syariah, Jurnal Ekonomi Syariah dan Filantropi Islam, Vol. 1, No. 2, 2017. 